\title{
Evaluation of flour protein for different bread wheat genotypes
}

\author{
M. A. Abdelaleem ${ }^{\text {* }}$ (D) and K. F. Al-Azab

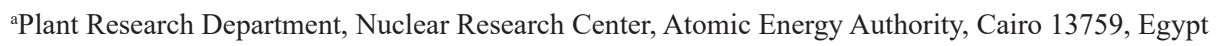 \\ *e-mail: Mdabdelrazek.md@gmail.com; Abdelrazek_MD@yahoo.com
}

Received: October 29, 2019 - Accepted: February 16, 2020 - Distributed: August 31, 2021

(With 2 figures)

\begin{abstract}
Six different bread wheat genotypes; two Egyptian commercial varieties (control); Giza-168 and Gemmeiza-11, and four promising lines; L84 and L148, resulted via hybridization and M10 and M34 via radiation mutation program) were rheologically evaluated using extensograph and for protein, analysis using sodium dodecyl sulfate polyacrylamide gel electrophoresis (SDS-PAGE). The radiation mutant M10 and M34 had the highest maximum resistance which is a very good indicator of strong gluten. The amount of gluten content was higher in M10, L148, and M34 compared to the control samples Gz168 and Gm11. Sulfide amino acids (CYS and MET) are slightly higher in M10. The electrophoretic results and amino acid analyzers show that the best technological quality was exhibited by M10. Radiation mutants wheat genotypes have a protein with good characteristics, mainly gluten which is significantly higher compared to control samples. The rheological properties measured as extensograph and gel electrophoresis were much better in irradiated lines M10 and M34.
\end{abstract}

Keywords: radiation mutation, extensograph, SDS-PAGE, sulfide amino acids, cysteine.

\section{Avaliação da proteína de farinha para diferentes genótipos de trigo de pão}

\section{Resumo}

Seis diferentes genótipos de trigo de pão, duas variedades comerciais egípcias (controle) - Giza-168 e Gemmeiza-11 - e quatro linhas promissoras - L84 e L148, obtidas via hibridação, e M10 e M34, via programa de mutação por radiação foram avaliados reologicamente por meio de extensógrafo, enquanto, para proteínas, foram feitas análises utilizando eletroforese em gel de poliacrilamida com dodecilsulfato de sódio (SDS-PAGE). Os mutantes de radiação M10 e M34 apresentaram a maior resistência máxima, o que é um indicador muito bom de glúten forte. A quantidade de glúten foi maior em M10, L148 e M34 em comparação com as amostras de controle Gz168 e Gm11. Os aminoácidos sulfurados (CYS e MET) são um pouco mais altos no M10. Os resultados eletroforéticos e analisadores de aminoácidos mostram que a melhor qualidade tecnológica foi exibida pelo M10. Os genótipos de trigo mutantes da radiação possuem uma proteína com boas características, principalmente o glúten, que é significativamente maior em comparação às amostras do grupo controle. As propriedades reológicas medidas, como extensógrafo e eletroforese em gel, foram muito melhores nas linhas irradiadas M10 e M34.

Palavras-chave: mutação de radiação, extensógrafo, SDS-PAGE, aminoácidos sulfídricos, cisteína.

\section{Introduction}

Wheat is one of the most important cereal crops of the world's population in more than 40 countries including Egypt and is the leading source of cereal protein in human food (Egypt, 2012; Ronda and Roobs, 2011). Several studies mainly focusing on the protein properties, with particular emphasis on gluten strength, as a direct imaging for baking performance. Thus, differences in baking quality among cultivars have been related to differences in gluten composition (Weegels et al., 1996; Wieser and Zimmermann, 2000). Determination of gluten strength and bread making properties of flour is very important in evaluating dough performance (Matos and Rosell, 2015). The extensograph test are classified as empirical (descriptive) test that

could determines and records the resistance of dough to stretching (Amjid et al., 2013; Bonet et al., 2006; Shelton, 2008). Gluten plays a key role in determining the quality of wheat flour (MacRitchie, 1994; Shewry and Tatham, 1997). Gluten proteins substantially control the quality of wheat flour products (Mac Ritchie, 1984).

The relationship between gluten proteins and elasticity of dough, and determining if this dough is suitable for bread making, was noticed by Wall (1979). So, the quality of bread is greatly associated with the flour's gluten protein compositions. It is well known that rheological properties of dough are dictated by the amount of proteins contained. However, rheological 
properties differ even when the amount of protein remains unchanged. This fact implies that these properties relate not only to the proteins quantity but also to their compositions (Singh et al., 1990; Gupta et al., 1992).

Gliadin is not only has a direct impact on the wheat quality in terms of dough strength, but also controls the quality of the end product (bread). The genetic linkage between gliadins and low molecular weight glutenin subunit (LMW - GS), is the assumption of the previous results (Gianibelli et al., 2001). Glutenins are polymeric protein that consist of two subunits connected with disulphide bonds; high molecular weight glutenin subunits (HMW - GS, $80-130 \mathrm{kDa}$ ) and low molecular weight glutenin subunits (LMW - GS, $10-70 \mathrm{kDa}$ ) as well as, these subunits are responsible for elasticity of gluten (Song and Zheng, 2008).

Furthermore, wheat proteins was calcified according to the solubility. Albumins were water soluble, globulins were salt soluble, gliadins alcohol soluble and the glutenins were divided into acid soluble and acid insoluble fractions. Some of dough characteristics is due to main fractions of total acid insoluble gliadin and glutenin where, dough strength and baking quality is significantly contributed to glutenin, while dough extensibility is significantly contributes to gliadin (Blakeney et al., 2009).

Wheat proteins are separated and characterized by acrylamide gel electrophoresis in the presence of sodium dodecyl sulfate technique by Bietz and Wall (1972). One of the most physical mutagens is $\gamma$-radiation, these mutagens are broadening genetic variability as well as, increasing means of cultivars thus, helping plant breeders to select and segregate followed generations starting from second generation $\left(\mathrm{M}_{2}\right)$ till stable mutated generation. However, $\gamma$-irradiation induce mutants in bread wheat for tolerance to drought leading to release of 26 varieties worldwide (Al-Naggar et al., 2007; FAO, 2012). On the other hand, regarding to irradiation of cereals, gamma irradiation is very effective for decontamination and disinfestation of cereals. No significant decreasing trend was observed in amino acids except methionine at a dosage of $10 \mathrm{kGy}$ and higher (Aziz et al., 2006).

Hence in this study, different genotypes of bread wheat were milled, evaluated by extensograph, analyzed of protein composition using SDS-Page and finally amino acids of protein flour were analyzed. The study hope serve as a guide in wheat breeding programs especially for promising bread wheat genotypes comes from gamma radiation mutation at low doses.

\section{Material and Methods}

The study was carried out at the experimental farm of the Plant Research Department, Nuclear Research Center, Inshas, Egypt during the two successive wheat growing seasons 2016/2017 through 2017/2018. The soil at the experimental site was loamy sand to sandy.

\subsection{Genetic materials}

Six bread wheat genotypes (Triticum aestivum L.), that were showed in Table 1; two Egyptian commercial varieties namely; Giza-168 and Gemmeiza-11, and four promising lines namely; L84, L148, M10 and M34 developed by the wheat breeding program of the Atomic Energy Authority, Inshas, Egypt, (Al-Azab-2013), were used in this investigation.

\section{Physiochemical analysis of wheat flour}

The wheat samples were milled on a Chopin laboratory mill (Chopen CD1). Before being milled, the samples were conditioned to $14.0 \%$ moisture for $20-24$ hours. Moisture and protein content for wheat after conditioning are analyzed. Wheat flour analyses that were presented in Table 2 were determined using (Perten IM9500, Sweden) and evaluated according to AACC (2000). These quality tests of wheat flour i.e.; protein content (AACC 46-12), wet gluten (AACC 38-12 A), gluten index (AACC 38-12 A) were evaluated according to AACC (2000).

\subsection{Rheological characteristics}

Dough rheological analyses which was consisted of flour $(100 \mathrm{~g})$, salt $(1.8 \mathrm{~g})$ and water (achieved by extensograph test) are described below. Extensograph characteristics were determined according to the ICC 114/1 and AACC 54-10 methods (ICC, 1996; AACC, 2000). The following parameters were determined in a Brabender extensograph: the dough Energy [A, $\left.\mathrm{cm}^{2}\right]$, Maximum Resistance [ $\mathrm{R}_{\text {max }}$, Brabender unit (BU)], Resistance at $5 \mathrm{~cm}\left[\mathrm{R}_{5 \mathrm{~cm}}, \mathrm{BU}\right]$, Extensibility $\left[\mathrm{E}_{\mathrm{x}}, \mathrm{mm}\right]$, ratio of Maximum Resistance to Extensibility $\left[\mathrm{R}_{\max } / \mathrm{E}_{\mathrm{x}}\right]$.

\subsection{SDS-PAGE analysis}

Grains of each sample were ground with liquid nitrogen to obtain fine powder then proteins profiling of samples

Table 1. Bread wheat genotypes.

\begin{tabular}{llc}
\hline \multicolumn{1}{c}{ Genotype } & \multicolumn{1}{c}{ Pedigree } & Maturity \\
\hline L84* & Sids 4 $*$ Giza-168 & Early \\
L148* & Maryout-5 $\times$ Giza-168 & Moderate \\
M10** & Sids-4 / 350Gy & Very early \\
M34** & Aseel-5 / 350Gy & Moderate /Late \\
Giza-168 (Gz168)*** & Mrl / Buc // Seri CM 930468M-0Y-0M-2Y-0B & Moderate \\
Gemmeiza11 (Gm11)*** & BOW"S"/KVZ"S"// 7C/SERI82/3/GIZA168/SKHA61 & Moderate \\
\hline
\end{tabular}

*Lines developed via hybridization; **Mutants developed via gamma radiation; ***Cultivars as control. 
was performed using SDS-PAGE according to Laemmli (1970) and the data obtained from SDS-PAGE was scored for the presence (1) and absence (0) of the bands and entered in a binary data matrix.

\subsection{Amino acid analysis}

Amino acids were quantitatively analyzed with the Biochrom 31 amino acid analyzer (Amersham, Britain) according to Xiao-ling et al. (2008). A known volume was injected into the amino acid analyzer to estimate the amino acid profile for each sample (tryptophan could not be determined by this method).

\subsection{Statistical analysis}

The results were expressed as the mean of three replicates. The data were statistically analyzed using SAS $^{\circledR} 9.2$ software (SAS, 2009). The general linear model procedure was applied and Duncan's multiple range test was used to compare the mean values at $\mathrm{P}<0.05$.

\section{Results and Discussion}

The gluten strength which playing an important role in predicting the industrial quality, is determined by the protein content of wheat flour (Fufa et al., 2005). The amount of protein in bread wheat was ranged from 6 to $28 \%$ (Lasztity, 1995). Dough has the viscoelastic ability due to the wheat protein content of both glutenin and gliadin, this ability is considered a unique characteristics. Main functional parts of gluten (gliadin and glutenin) have inter and intra-molecular disulfide bonds. Gliadin, with intra-molecular disulfide bonds, is responsible for the dough cohesiveness, while glutenin, with inter- and intra-molecular disulfide bonds, is responsible for elasticity of dough (Veraverbeke and Delcour, 2002).

Table 2 represented the amount of protein in whole wheat grain and wheat flour as well as, the amount of gluten in wheat flour of the six samples. These wheat grains and flours had significant differences $(p<0.05)$ in their protein content and therefore serve as our experimental samples. The amount of protein content in whole wheat showed significant differences among most of samples, though the highest amount of protein in flour found in sample M10 (the mutants sample) $14.1 \%$. As well as, wet gluten increased significantly in mutant samples (M10 and M34) compared to control samples (Gz168 and Gm11) due to irradiation treatment. This finding was also found by Lee et al. (2017) where wet gluten was increased by gamma irradiation. So, the flour that had high amount of protein plays a crucial role in forming the strong, cohesive dough. In addition, gas is trapped and produce light backed products. The previous properties represent great diversity of wheat products; pasta, noodles, cookies, and breads (Day et al., 2006; Laze et al., 2019).

Further studies by Shelton (2008) revealed that the protein content is the way to determine wheat and flour purchases, i.e., water absorption and gluten strength. Moreover, protein content can be related to end-product attributes, i.e., texture and appearance. High protein content is used for products with chewy texture, i.e., pan bread and hearth bread where, low protein content is used for crisp or tender products, i.e., snacks or cakes.

\subsection{Rheological characteristics (Extensograph parameters)}

Extensograph tests performed on six bread wheat genotypes (L84, L148, M10, M34, Gz168 and Gm11) in order to assess their technological quality. The obtained data showed that there were some differences in the values of specified parameters Table 3 and Figure 1.

The water absorption of dough is significantly $(\mathrm{P}<0.05)$ increased in the samples L148, M10 and L84 compared to control samples except for sample M34. In addition, all extensograph parameters, i.e., dough energy, maximum resistance, resistance at $5 \mathrm{~cm}$ and extensibility were significantly $(\mathrm{P}<0.05)$ increased in sample M10 compared to all samples under investigations. Extensibility generally increases with protein content and it is desirable for dough strength to respond in this way as well (Blakeney et al., 2009).

Radiation mutation at dose 350 Gy might be responsible for the highest increment in extensograph characteristics of dough. Similar findings are obtained by Teixeira et al. (2012) who found that the extensibility value is increased due to generated modification in gluten structure when wheat flour is subjected to irradiation treatment. Furthermore, Ibrahim (2008) found that irradiation treatment at dose 500 Gy of different cultivars of flour wheat increased the dough energy, resistance and extensibility compared to control samples. The extensograph properties of dough with good breadmaking quality include high resistance

Table 2. Protein and gluten content of flour of six wheat genotypes.

\begin{tabular}{|c|c|c|c|c|}
\hline \multirow{2}{*}{ Genotypes } & \multicolumn{2}{|c|}{ Protein \% (on dry base) } & \multirow{2}{*}{ Wet Gluten (\%) } & \multirow{2}{*}{ Gluten index $(\%)$} \\
\hline & Whole Wheat grain & Wheat Flour & & \\
\hline L84 & $15.1^{\mathrm{d}} \pm 0.06$ & $13.3^{b} \pm 0.15$ & $39.3^{\mathrm{e}} \pm 0.11$ & $35^{\mathrm{a}} \pm 0.6$ \\
\hline L148 & $14.6^{c} \pm 0.10$ & $14.0^{\mathrm{b}} \pm 0.57$ & $35.1^{\mathrm{c}} \pm 1.20$ & $55^{\mathrm{b}} \pm 0.0$ \\
\hline M10 & $15.0^{\mathrm{d}} \pm 0.06$ & $14.1^{\mathrm{b}} \pm 0.06$ & $36.4^{\mathrm{cd}} \pm 0.06$ & $87 \mathrm{c} \pm 0.5$ \\
\hline M34 & $16.0^{\mathrm{e}} \pm 0.03$ & $13.7^{\mathrm{b}} \pm 0.11$ & $37.2^{\mathrm{d}} \pm 0.08$ & $61^{\mathrm{d}} \pm 0.0$ \\
\hline Gz168 & $12.8^{b} \pm 0.06$ & $11.1^{\mathrm{a}} \pm 0.08$ & $30.8^{b} \pm 0.09$ & $45^{\mathrm{e}} \pm 0.6$ \\
\hline Gm11 & $12.1^{\mathrm{a}} \pm 0.06$ & $10.7^{\mathrm{a}} \pm 0.31$ & $27.3^{\mathrm{a}} \pm 0.06$ & $70^{f} \pm 0.6$ \\
\hline
\end{tabular}

Values are means \pm S.E. of three replicates; Values followed by different letters in the same column are significantly different $(\mathrm{P}<0.05)$ using Duncan's test. 
Table 3. Extensograph parameters of wheat flour of six wheat genotypes.

\begin{tabular}{|c|c|c|c|c|c|c|c|}
\hline & Time & L84 & L148 & M10 & M34 & Gz168 & Gm11 \\
\hline WA (\%) & \multirow{6}{*}{135 min. } & $60.1^{\mathrm{cd}} \pm 0.05$ & $63.2^{\mathrm{e}} \pm 0.11$ & $61.33^{\mathrm{d}} \pm 0.66$ & $58.7^{\mathrm{b}} \pm 0.66$ & $51.5^{\mathrm{a}} \pm 0.23$ & $59.5^{\mathrm{bc}} \pm 0.28$ \\
\hline $\mathrm{E}\left(\mathrm{cm}^{2}\right)$ & & $81^{c} \pm 0.5$ & $69^{b} \pm 2.3$ & $158^{\mathrm{e}} \pm 0.5$ & $88^{d} \pm 3.7$ & $58^{\mathrm{a}} \pm 0.6$ & $62^{\mathrm{a}} \pm 0.3$ \\
\hline $\mathbf{R}_{\text {max. }}(\mathrm{BU})$ & & $417^{b} \pm 0.3$ & $432^{c} \pm 0.6$ & $904^{\mathrm{f}} \pm 2.6$ & $553^{\mathrm{e}} \pm 2.1$ & $403^{a} \pm 0.3$ & $462^{\mathrm{d}} \pm 1.1$ \\
\hline $\mathbf{R}_{5 \mathrm{~cm}}(\mathrm{BU})$ & & $325^{\mathrm{a}} \pm 0.57$ & $356^{\mathrm{b}} \pm 3.7$ & $512^{\mathrm{f}} \pm 0.3$ & $400^{\mathrm{d}} \pm 5.7$ & $389^{c} \pm 1.7$ & $427^{e} \pm 4.3$ \\
\hline$E_{x}(\mathbf{m m})$ & & $139^{\mathrm{e}} \pm 1.5$ & $117^{c} \pm 0.5$ & $141^{\mathrm{e}} \pm 0.6$ & $127^{\mathrm{d}} \pm 2.9$ & $46^{\mathrm{a}} \pm 2.8$ & $97^{\mathrm{b}} \pm 2.0$ \\
\hline $\mathbf{R}_{\text {max. }} / \mathbf{E}_{\mathrm{x}}$ ratio & & $3.0^{\mathrm{a}} \pm 0.2$ & $3.7^{\mathrm{a}} \pm 0.1$ & $6.4^{c} \pm 0.1$ & $3.1^{\mathrm{a}} \pm 0.2$ & $8.7^{\mathrm{d}} \pm 0.1$ & $4.7^{b} \pm 0.5$ \\
\hline
\end{tabular}

$\mathrm{WA}=$ Water Absorption; $\mathrm{E}=$ Dough Energy; $\mathrm{R}_{\mathrm{max}}=$ Maximum Resistance; $\mathrm{R}_{5 \mathrm{~cm}}=$ Resistance at $5 \mathrm{~cm} ; \mathrm{E}_{\mathrm{x}}=$ Extensibility; $\mathrm{R}_{\max } / \mathrm{E}_{\mathrm{x}}=$ Maximum Resistance/Extensibility ratio; $\mathrm{BU}=$ Brabender unit; Values are means \pm S.E. of three replicates; Values followed by different letters in the same row are significantly different $(\mathrm{P}<0.05)$ using Duncan's test.
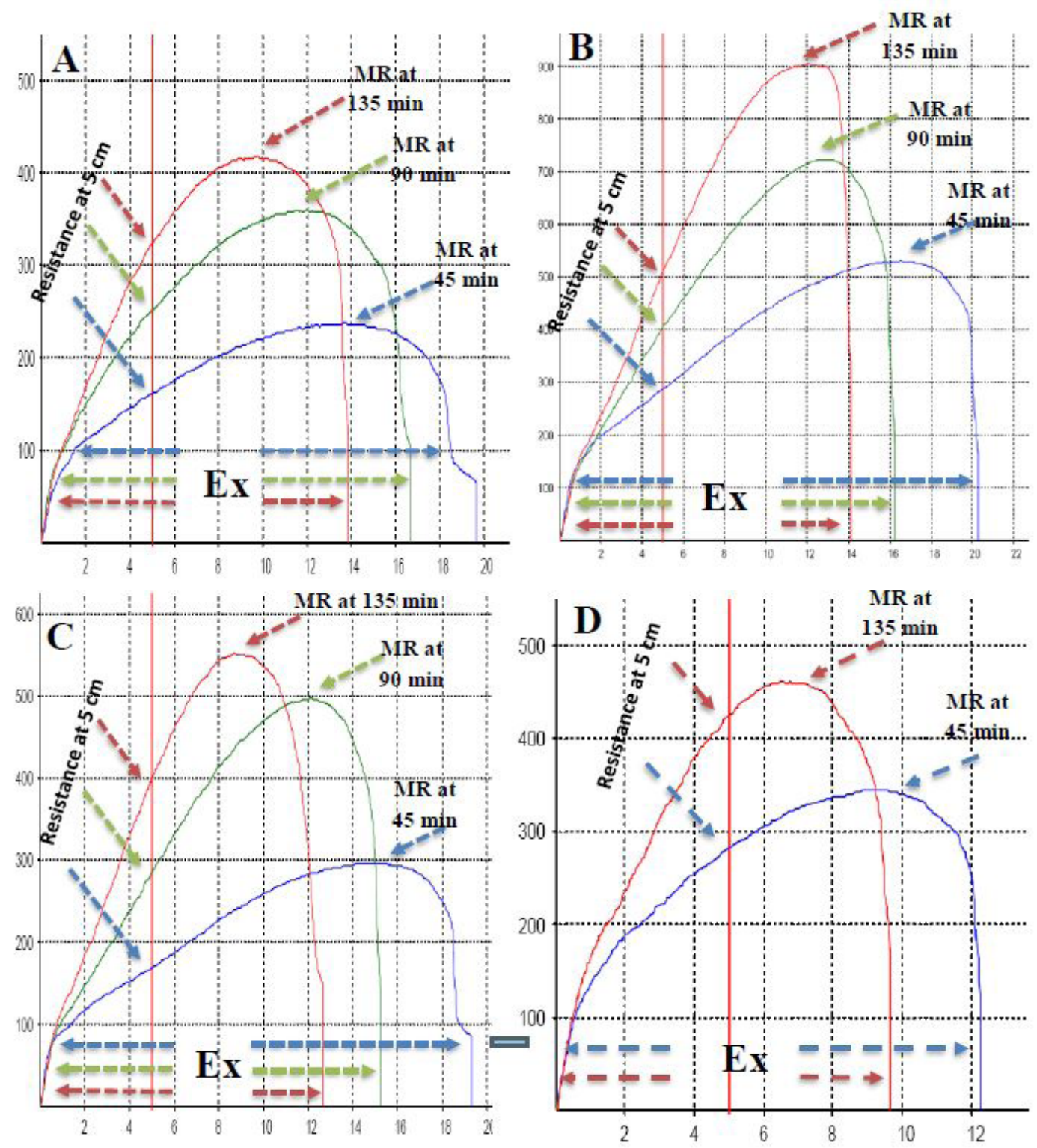

Figure 1. Extensogram of (A) hybridized bread wheat line L148 (B) radiation mutation bread wheat M10 (C) radiation mutation bread wheat M34 and (D) control bread Gemmeiza 11 (Gm11), (Ex) Extensibility, (MR) Maximum Resistance. 
to extension, high dough energy and long extensibility (Shelton, 2008; Slumir, 2005).

\subsection{SDS-PAGE analysis}

In the present study the protein components of gluten protein (GP) like; gliadin ( $\alpha-, \beta-, \gamma-$, and $\omega$ - gliadin) and glutenin [Low molecular weight (LMW) and High molecular weight (HMW)], and non-gluten protein (NGP) like; albumin and globulin of different bread wheat varieties were separated by SDS-PAGE electrophoresis for characterization and evaluation of genetic diversity among the given set of genotypes. Proteins banding pattern of different wheat verities are showed in electrophorogram in Figure 2. The molecular weight marker in our study

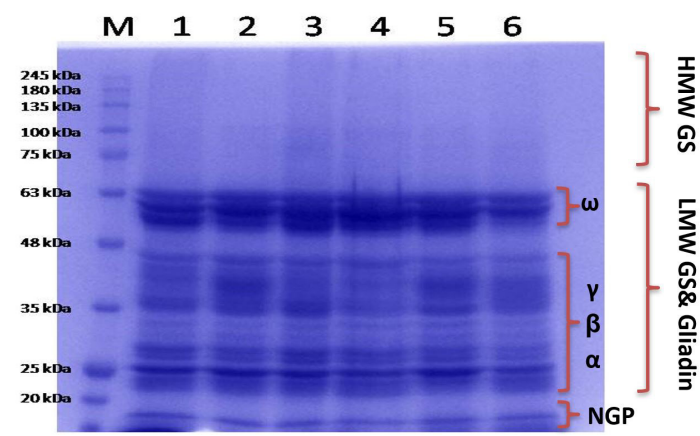

Figure 2. Electrophorogram showing banding pattern of wheat proteins of different genotypes; $\mathrm{M}=$ Marker, $1=\mathrm{L} 148$; $2=\mathrm{L} 84 ; 3=\mathrm{M} 10 ; 4=\mathrm{M} 34 ; 5=\mathrm{Gz} 168 ; 6=\mathrm{Gm} 11 ; \mathrm{HMW}$ GS = High molecular weight glutenin subunits; LMW $\mathrm{GS}=$ low molecular weight glutenin subunits; $\alpha, \beta, \gamma$, $\omega=$ Gliadin fractions; NGP = Non-gluten protein. from 10 to $245 \mathrm{kDa}$ was used, while Shuaib et al. (2010) mentioned that the range from 10 to $200 \mathrm{kDa}$.

The results in Table 4 showed that the total number of bands with ranged from 14 to 16 in different genotypes. The bands on the gel were differed in the intensity of the band color on the gels, which represents different quantitative profiles of gluten fractions, that is, reflected in a similar distribution of protein bands in the bars as well as glutenin and gliadin. However, Figure 2 and Table 4 showed that the lane numbers 2, 3, 4 and 6 representing the genotypes L84, M10, M34 and Gm11, respectively, had less number of protein bands as compared to the other genotypes L148 and Gz168.

In Figure 2, the electrophoretic testing of gluten fractions, the largest number of protein bands are located in the area of molecular mass of 23 and $62 \mathrm{kDa}$, the area of $(\beta, \gamma$, and $\omega)$ glutenin and gliadin (LMW). The obtained results are the same trend with Tomić and Torbica (2011) who found the area ranged between 35 and $60 \mathrm{kDa}$. Meanwhile, separation of gliadin from glutenin in solution is similar to protein separation where, the theory of separation is depending on size. These methods like; size-exclusion high-performance liquid chromatography (SE-HPLC), size-based capillary electrophoresis, field flow fractionation (FFF), sizebased gel electrophoresis, and gel filtration (Wrigley et al., 2006).

Furthermore, in Figure 2 the small area located below the molecular mass 23 showed the non-gluten protein (NGP) which is ranged from 18 to $25 \%$ (Table 5). Also, Veraverbeke and Delcour (2002) mentioned that the NGP are mainly lower than $25 \mathrm{kDa}$. The same average percentage of NGP was found also by Merlino et al. (2009)

Table 4. Polymorphism of wheat gluten bands.

\begin{tabular}{lcccccc}
\hline & L148 & L84 & M10 & M34 & Gz168 & Gm11 \\
\hline Monomorphic & 9 & 9 & 9 & 9 & 9 & 9 \\
Polymorphic(without unique) & 5 & 6 & 5 & 6 & 7 & 2 \\
Unique & $\mathbf{2}$ & $\mathbf{0}$ & $\mathbf{1}$ & $\mathbf{0}$ & $\mathbf{0}$ & $\mathbf{3}$ \\
Polymorphic(with unique) & 7 & 6 & 6 & 6 & 7 & 5 \\
Total bands & $\mathbf{1 6}$ & $\mathbf{1 5}$ & $\mathbf{1 5}$ & $\mathbf{1 5}$ & $\mathbf{1 6}$ & $\mathbf{1 4}$ \\
\hline
\end{tabular}

Table 5. Classification of wheat gluten and non-gluten proteins.

\begin{tabular}{|c|c|c|c|c|c|c|}
\hline Protein content $(\%)$ & L148 & L84 & M10 & M34 & Gz168 & Gm11 \\
\hline Gliadin and Glutenin (gluten protein) & 81.3 & 80.0 & 80.0 & 80.0 & 75.0 & 78.6 \\
\hline Non Gluten protein & 18.8 & 20.0 & 20.0 & 20.0 & 25.0 & 21.4 \\
\hline \multicolumn{7}{|l|}{ Gliadin content (\%) } \\
\hline$\alpha$ Gliadin & 23.1 & 25.0 & 25.0 & 25.0 & 16.7 & 27.3 \\
\hline$\beta, \gamma$ Gliadin & 53.8 & 50.0 & 50.0 & 50.0 & 58.3 & 54.5 \\
\hline$\omega$ Gliadin & 23.1 & 25.0 & 25.0 & 25.0 & 25.0 & 18.2 \\
\hline \multicolumn{7}{|l|}{ Glutenin content $(\%)$} \\
\hline LMW GS & 76.9 & 75.000 & 75.0 & 75.0 & 75.0 & 81.8 \\
\hline
\end{tabular}

LMW GS = low molecular weight glutenin subunits. 
and Zilic et al. (2011) who stated that about $20 \%$ of the total wheat protein is albumins and globulins.

Mostly, the general opinion that the secondary role in influencing the flour quality tends to the albumins and globulins (Gianibelli et al., 2001; Singh et al., 2011). The polymorphism of wheat gluten bands is presented in Table 4. The monomorphic bands are mainly the most exhibited bands of total protein band in all samples under study. Gliadin proteins, with intra-polypeptide in disulfide bonds, are the gluten proteins in the form of monomeric polypeptides in flour extract.

Non-gluten protein are mainly monomeric but both albumins and globulins tend to form polymers by forming inter-chain disulphide (Veraverbeke and Delcour, 2002). In addition, albumins are mostly monomeric physiologically active proteins (Goesaert et al., 2005). On the other hand, the polymorphic bands either with or without unique bands are lower in number than monomorphic bands (Table 4). Wrigley et al. (2006) mentioned that glutenin are polymeric protein, with disulfide bonds combine individual polypeptides of glutenin together. Meanwhile, the bands particularly Line number 1 (L148), 4 (M10) and 6 (Gm11) were unique among most of the genotypes.

Regarding to radiation mutation, the obtained mutant M10 came from low radiation dose program (350 Gy) showed slight effects on wheat protein compared to wheat protein of the study by Le Maire et al. (1990) who treated wheat flour with $10 \mathrm{kGy} \gamma$-radiation and found a sharp reduction in the quantity of protein in SDS-Page. However, our study are in agreement with Stoklosa et al. (2012) in using low radiation doses.

In previous studies, wheat directly exposed to elevated radiation from 50 to $100 \mathrm{kGy}$, dramatic changes were found, protein degradations (Deschreider, 1996), specific and nonspecific amino acid damage (Patten and Gordy, 1964), disruption in hydrogen bond (Williams and Hunt, 1963) and disulfide bonds splitting (Doguchi, 1969).

\subsection{Chemical composition of Gluten}

Protein quality is related to its gluten properties and formation. When wheat flour is washed with water, starch, non-starchy polysaccharides and water-soluble constituents are drained and ruby mass (gluten) is left. About $80-85 \%$ of total weight content of gluten is protein, $5 \%$ for lipids and the mostly remainder is starch and non-starch carbohydrates (Wall, 1979; Wieser, 2007).

Table 5 summarized the classifications of wheat gluten and non-gluten proteins. The gluten protein (GP) ranged from $75 \%(\mathrm{Gz} 168)$ to $81.3 \%(\mathrm{~L} 148)$ of total protein in samples under investigation. While, non-gluten protein (NGP) ranged from $18.8 \%$ (L148) to $25 \%$ (Gz168) of total protein.

Gluten combines starch granules in a surrounded matrix and then consists of hundreds protein components which are represent either as monomers or, as olig-polymers (collected together by inter/intra- disulfide bonds) (Wrigley and Bietz, 1988; D' Ovidio and Masci, 2004; Torbica et al., 2016). Thus, the relation between gliadin and glutenin is mainly needed to form dough. During the early stage of mixing a dough is not formed even though all the water may have been absorbed. Gluten is composed from the mixture of gliadin and glutenin, the mixture formed viscoelastic matrix may differ in the number of hydrogen bonds in both gliadin and glutenin molecules. However, glutenin is mainly determined the rate of interaction due to its specific surface area (Sapirstein and Fu, 2000).

It is widely accepted that gliadin accounts for the viscous properties, and glutenin imparts the strength and elasticity that are necessary to hold the gases that are produced during fermentation and baking (Khatkar et al., 1995; Módenes et al., 2009). Gliadin surface is considered hydrophobic in its native state (Arangoa et al., 2000). The higher exposure dose of gamma radiation to protein, increased availability of hydrophilic amino acids (Matloubi et al., 2004). High dose of irradiation treatment about $10 \mathrm{kGy}$ and above caused gliadin protein is more adhesive and compact. Moreover, the environmental factors is mainly affected protein content while, genetics playing a minor role in protein (low or high) content (Blakeney et al., 2009). However, low doses either used in inducing wheat mutants or used in treated wheat flour, were make slight changes might be useful and promising in bread making.

\subsection{Amino acid composition of bread wheat genotypes}

As shown in Table 6, the analysis of amino acids in the wheat grain showed differences between examined wheat genotypes. Qualitative analysis represented the differences in amino acid composition where, seventeen different amino acid have been identified.

Table 6. Amino acid composition of wheat gluten of two genotypes.

\begin{tabular}{lcc}
\hline Amino acid & Gm11 $^{*}$ & M10 $^{* *}$ \\
\hline Aspartic (ASP) & 6.4 & 5.74 \\
Therionine (THR) & 3.25 & 2.84 \\
Serine (SER) & 4.7 & 4.1 \\
Glutamic (GLU) & 28.5 & 28.44 \\
Glycine (GLY) & 4.55 & 4.51 \\
Alanine (ALA) & 4.45 & 4.75 \\
Valine (VAL) & 4.77 & 4.61 \\
Isoleucine (ILE) & 3.8 & 3.4 \\
Leucine (LEU) & 6.3 & 6.95 \\
Tyrosine (TYR) & 3.42 & 3.45 \\
Phenylalanine (PHE) & 5.14 & 4.89 \\
Hisitidine (HIS) & 2.7 & 2.55 \\
Lysine (LYS) & 3.36 & 2.84 \\
Argnine (ARG) & 5.85 & 5.18 \\
Proline (PRO) & 9.45 & 10.5 \\
Cysteine (CYS) & 2.05 & 3.26 \\
Methionine (MET) & 1.31 & 1.99 \\
Total & $\mathbf{1 0 0}$ & $\mathbf{1 0 0}$ \\
\hline
\end{tabular}

*Cultivars as control and expressed on $14.1 \%$ protein basis; **Mutants developed via gamma radiation and expressed on $10.7 \%$ protein basis. 
The content of glutamic amino acids was $28.44 \%$ and $28.50 \%$ in sample M10 and Gm11, respectively.

The protein amino acid fractions; glutamine, proline, glycine and cysteine exhibit similarities in proportions in different cereals and bread wheat genotypes. Quantitative analysis of protein bread wheat showed that the highest percentage of all identified amino acids presented in glutamic acid, glycine and proline (Knežević et al., 2013). Glutamic acid, the main amino acids in all cereal protein, is played an important role in metabolism of nitrogen in cell in addition, gliadins storage glutamic acid as glutamine.

Glutamine is the most abundant amino acid in gluten proteins and chiefly responsible for the water-binding capacity of gluten. In fact, dry gluten absorbs about twice its own weight of water. Moreover, glutamine residues are involved in frequent protein-protein hydrogen bonds (Bauer et al., 2003).

On the other hand, proline content was increased sample M10 (mutant sample) compared to sample Gm11 (control sample). Our obtained results are in the same trend with (Bachiri et al., 2014) who mentioned that the proline content was increased in gamma irradiated sample at dose $150 \mathrm{~Gy}$ compared to non-treated samples. The accumulation in the proline content had been demonstrated in many cereal and grains and in different cases of stress (Al-Rumaih and Al-Rumaih, 2008).

As previously mentioned in Table 1 sample M10, mutant via gamma radiation at dose $350 \mathrm{~Gy}$, showed higher amount of sulfide amino acids, i.e., cysteine (3.26\%) and methionine (1.99\%) compared to sample Gm11 (2.05\%) and $(1.31 \%)$, respectively. Generally in gluten protein amino acids, cysteine residues even in a minor amounts played an essential role in gluten functions and structure.

Cysteine (oxidized form) normally form inter-chain disulphide bonds within and between proteins (Wieser, 2007). The main functional goal of disulfide bonds is determining of both structure and properties of wheat gluten proteins. Disulphide bonds are formed between sulfhydryl groups of cysteine residues, either within a single protein (intra-chain) or between proteins (inter-chain) (Koehler and Wieser, 2003). The increment in disulphide bonds due to the act of free radicals as oxidizing agents causing more s-s groups in the dough resulting in high resistance to extension (Ibrahim, 2008).

Intra-chain disulfide bonds is formed by cysteine residues in S-rich prolamins ( $\alpha$-type gliadins, $\gamma$-type gliadins and LMW-subunits) while, inter-chain disulfide bonds is formed by cysteines residues found only in LMW (Shewry and Tatham, 1997).

\section{Conclusion}

From the results of this study it is concluded that rheological assessment and evaluation of genetic diversity and identification of wheat genotypes by SDS-PAGE is playing an important role in molecular weight analysis of wheat proteins. The study could help in improving the efficiency of wheat breeding programs in cultivars development especially in developing countries like
Egypt. Breeders handle thousands of promising lines and mutants induced via gamma radiation to be whittled down to the few lines and mutants that may end up as varieties. Therefore, radiation mutation could be one of the promising treatments in plant breeding programs. Furthermore, the breeding program to be successful quality wise, the breeder needs to work with a cereal chemist who manages a laboratory that has all the equipment needed to screen breeding lines at the different stages of their development in the breeding process.

\section{Acknowledgments}

The authors appreciate the valuable assistance to Dr. Ibrahim Osamy, Genetic Unite, Plant Research Department, Nuclear Research Center, Egyptian Atomic Energy Authority.

\section{References}

AL-NAGGAR, A.M.M., ATTA, M.M., SHAHEEN, A.M. and AL-AZAB, K.F., 2007. Gamma rays and EMS induced drought tolerant mutants in bread wheat. Egypt J. Plant Breed, vol. 11, no. 3, pp. 135-165.

AL-RUMAIH, M. and AL-RUMAIH, M., 2008. Influence of Ionizing Radiation on Antioxidant Enzymes in Three Species of Trigonella. American Journal of Environmental Sciences, vol. 4, no. 2, pp. 151-156. http://dx.doi.org/10.3844/ajessp.2008.151.156.

AMERICAN ASSOCIATION OF CEREAL CHEMISTS - AACC, 2000. Approved Methods of the AACC. 10th ed. St. Paul: AACC.

AMJID, M.R., SHEHZAD, A., HUSSAIN, S., SHABBIR, M.A. and KHAN, M.R., 2013. A Comprehensive review on wheat flour dough rheology. Pakistan Journal of Food Sciences, vol. 23, no. 2, pp. 105-123.

ARANGOA, M.A., PONCHEL, G., ORECCHIONI, A.M., RENEDO, M.J., DUCHENE, D. and IRACHE, J.M., 2000. Bioadhesive potential of gliadin nanoparticulate systems. European Journal of Pharmaceutical Sciences, vol. 11, no. 4, pp. 333-341. http:// dx.doi.org/10.1016/S0928-0987(00)00121-4. PMid:11033077.

AZIZ, N.H., SOUZAN, R.M. and SHAHIN AZZA, A., 2006. Effect of $\gamma$-irradiation on the occurrence of pathogenic microorganisms and nutritive value of four principal cereal grains. Applied Radiation and Isotopes, vol. 64, no. 12, pp. 1555-1562. http:// dx.doi.org/10.1016/j.apradiso.2005.10.006. PMid:16504526.

BACHIRI, H., DJEBBAR, R. and DJENADI, C., 2014. Gamma irradiation effects on some physiological traits of wheat (Triticum aestavium L.) under control and water stress conditions. American Journal of Plant Physiology, vol. 9, no. 3, pp. 103-109. http:// dx.doi.org/10.3923/ajpp.2014.103.109.

BAUER, N., KOEHLER, P., WIESER, H. and SCHIEBERLE, P., 2003. Studies on the effects of microbial transglutaminase on gluten proteins of wheat. I. Biochemical analysis. Cereal Chemistry, vol. 80, no. 6, pp. 781-786. http://dx.doi.org/10.1094/ CCHEM.2003.80.6.781.

BIETZ, J.A. and WALL, J.S., 1972. Wheat gluten subunits: molecular Weights determined by sodium sulfate-polyacrylamide gel electrophoresis. Cereal Chemistry, vol. 49, pp. 416-430.

BLAKENEY, A.B., CRACKNELL, R.L., CROSBIE, G.B., JEFFERIES, S.P., MISKELLY, D.M., O’BRIEN, L., PANOZZO, 
J. F., SUTER, D. A. I., SOLAH, V., WATTS, T., WESTCOTT, T. and WILLIAM, R. M., 2009. Understanding of wheat flour quality: a basic introduction to Australian wheat quality. Australia: Grains Research and Development Corporation, pp. 40.

BONET, A., ROSELL, C.M., CABALLERO, P.A., GOMEZ, M., PEREZ-MUNUERA, I. and LLUCH, M.A., 2006. Glucose oxidase effect on dough rheology and bread quality: a study from macroscopic to molecular level. Food Chemistry, vol. 99, no. 2, pp. 408-415. http://dx.doi.org/10.1016/j.foodchem.2005.07.043.

D'OVIDIO, R. and MASCI, S., 2004. The low-molecular-weight glutenin subunits of wheat gluten. Journal of Cereal Science, vol. 39, no. 3, pp. 321-339. http://dx.doi.org/10.1016/j.jcs.2003.12.002.

DAY, L., AUGUSTIN, M.A., BATEY, I.L. and WRIGLEY, C.W., 2006. Wheat-gluten uses and industry needs. Trends in Food Science \& Technology, vol. 17, no. 2, pp. 82-90. http://dx.doi. org/10.1016/j.tifs.2005.10.003.

DESCHREIDER, A.R., 1996. Action of the gamma rays on the constituent elements of the wheat flour. In: Proceedings of International Atomic Energy Agency Symposium, 1996, Karlsruhe, Germany. Vienna: IAEA

DOGUCHI, M., 1969. Effects of gamma irradiation on wheat gluten. Agricultural and Biological Chemistry, vol. 33, no. 12, pp. 1769-1774. http://dx.doi.org/10.1080/00021369.1969.10859535.

EGYPT. MINISTRY OF AGRICULTURE AND LAND RECLAMATION - MALR, 2012. Agricultural statistics of Arab Republic of Egypt, Arabic. Egypt: MALR.

FOOD AND AGRICULTURE ORGANIZATION - FAO and INTERNATIONALATOMIC ENERGY AGENCY - IAEA, 2012, Mutant variety database. Cereals and legumes. Vienna: FAO/IAEA.

FUFA, H., BAENZIGER, P.S., BEECHER, B.S., DWEIKAT, I., GRAYBOSCH, R.A. and ESKRIDGE, K.M., 2005. Comparison of phenotypic and molecular marker-based classifications of hard red winter wheat cultivars. Euphytica, vol. 145, no. 2, pp. 133146. http://dx.doi.org/10.1007/s10681-005-0626-3.

GIANIBELLI, M.C., LARROQUE, O.R., MACRITCHIE, F. and WRIGLEY, C.W., 2001. Biochemical, genetic, and molecular characterization of wheat endosperm proteins. St. Paul: AACC.

GOESAERT, H., BRIJS, K., VERAVERBEKE, W.S., COURTIN, C.M., GEBRUERS, K. and DELCOUR, J.A., 2005. Wheat flour constituents: how they impact bread quality, and how to impact their functionality. Trends in Food Science \& Technology, vol. 16, no. 1-3, pp. 12-30. http://dx.doi.org/10.1016/j.tifs.2004.02.011.

GUPTA, R.B., BATEY, I.L. and MACRITCHIE, F., 1992. Relationships between protein composition and functional properties of wheat flours. Cereal Chemistry, vol. 69, pp. 125-131.

IBRAHIM, E.I.E., 2008. Influence of gamma irradiation on the physicochemical properties of the two Sudanese wheat (Triticum aestivum) cultivars. Sudan: Faculty of Agriculture, Khartoum University, 89 p. M.Sc in Food Science and Technology.

INTERNATIONALASSOCIATION FOR CEREAL SCIENCEAND TECHNOLOGY - ICC, 1996. Standard methods of the international association for cereal science and technology. Vienna: ICC.

KHATKAR, B.S., BELL, A.E. and SCHOFIELD, J.D., 1995. The dynamic rheological properties of glutens and gluten subfractions from wheats of good and poor bread making quality. Journal of Cereal Science, vol. 22, no. 1, pp. 29-44. http://dx.doi. org/10.1016/S0733-5210(05)80005-0.
KNEŽEVIĆ, D., MIHAJLOVIĆ, D. and KONDIĆ, D., 2013. Contents of amino acids in grains of different bread wheat genotypes. Agro-knowledge Journal, vol. 14, no. 3, pp. 431-439. http://dx.doi.org/10.7251/AGREN1303431K.

KOEHLER, P. and WIESER, H., 2003, Chemistry of cereal grains. In M. Gobbetti and M. Gänzle, eds. Handbook on sourdough biotechnology. New York: Springer, pp. 11- 45.

LAEMMLI, U.K., 1970. Cleavage of structural proteins during the assembly of the head of bacteriophage T4. Nature, vol. 227, no. 5259 , pp. $680-685$. http://dx.doi.org/10.1038/227680a0. PMid:5432063.

LÁSZTITY, R., 1995. The chemistry of cereal proteins. 2nd ed. Boca Raton: CRC Press.

LAZE, A., ARAPI, V., CECA, E., GUSHO, K., PEZO, L., BRAHUSHI, F. and KNEŽEVIC, D., 2019. Chemical composition and amino acid content in different genotypes of wheat flour. Periodica Polytechnica. Chemical Engineering, vol. 63, no. 4, pp. 618-628. http://dx.doi.org/10.3311/PPch.13185.

LE MAIRE, M., THAUVETTE, L., DE FORESTA, B., VIEL, A., BEAUREGARD, G. and POTIER, M., 1990. Evidence of non-random fragmentations and a caution in the use of the method for determination of molecular mass. The Biochemical Journal, vol. 267, no. 2, pp. 431-439. http://dx.doi.org/10.1042/ bj2670431. PMid:2334402.

LEE, N.-Y., KANG, C.-S. and KIM, H.-S., 2017. Effects of $\gamma$-irradiation on the quality changes of fresh noodles prepared from wheat cultivated with $\mathrm{N}$-fertilization treatments. Food Science and Biotechnology, vol. 26, no. 1, pp. 135-142. http://dx.doi. org/10.1007/s10068-017-0018-1. PMid:30263520.

MACRITCHIE, F., 1984. Baking quality of wheat flours. Advances in Food Research, vol. 29, pp. 201-277. http://dx.doi.org/10.1016/ S0065-2628(08)60058-0.

MACRITCHIE, F. 1994, Role of polymeric proteins in flour functionality. In: Wheat kernel proteins: molecular and functional aspects. New York: Pergamon Press, pp. 145-150.

MATLOUBI, H., AFLAKI, F. and HADJIEZADEGAN, M., 2004. Effect of gamma-irradiation on amino acids content of baby food protein. Journal of Food Composition and Analysis, vol. 17, no. 2, pp. 133-139. http://dx.doi.org/10.1016/j.jfca.2003.09.005.

MATOS, M.E. and ROSELL, C.M., 2015. Understanding gluten-free dough for reaching breads with physical quality and nutritional balance. Journal of the Science of Food and Agriculture, vol. 95, no. 4, pp. 653-661. http://dx.doi.org/10.1002/jsfa.6732. PMid:24816770

MERLINO, M., LEROY, P., CHAMBON, C. and BRANLARD, G., 2009. Mapping and proteomic analysis of albumin and globulin in hexaploid wheat kernels (Triticum aestivum L.). Theoretical and Applied Genetics, vol. 118, no. 7, pp. 1321-1337. http://dx.doi. org/10.1007/s00122-009-0983-8. PMid:19277600.

MÓDENES, A.N., SILVA, A.M. and TRIGUEROS, D.E.G., 2009. Avaliação das propriedades reológicas do trigo armazenado. Food Science and Technology (Campinas), vol. 29, no. 3, pp. 508-512. http://dx.doi.org/10.1590/S0101-20612009000300008.

PATTEN, R.A. and GORDY, W., 1964. Further studies of radiation effects on the proteins and their constituents. Radiation Research, vol. 22, no. 1, pp. 29-34. http://dx.doi.org/10.2307/3571695. PMid:14157358. 
RONDA, F. and ROOBS, Y.H., 2011. Staling of fresh and frozen gluten free bread. Journal of Cereal Science, vol. 53, no. 3, pp. 220-227. http://dx.doi.org/10.1016/j.jcs.2011.02.004.

SAPIRSTEIN, H.D. and FU, B.X., 2000. Evidence for varying interaction of gliadin and glutenin proteins as an explanation for differences in gluten strength of different wheats. In: P.R. SHEWRY and A.S. TATHAM, eds. Wheat gluten. Cambridge: Royal Soc. Chem, pp. 425-429.

SAS INSTITUTE - SAS, 2009. Statistical analysis systemuser's guide. Cary: SAS Institute Inc.

SHELTON, D., 2008. Wheat and flour testing methods: a guide to understanding wheat and flour quality: Version 2. USA: Kansas State University.

SHEWRY, P.R. and TATHAM, A.S., 1997. Mini review: disulphide bonds in wheat gluten proteins. Journal of Cereal Science, vol. 25, no. 3, pp. 207-227. http://dx.doi.org/10.1006/jcrs.1996.0100.

SHUAIB, M., JAMAL, M., AKBAR, H., KHAN, I. and KHALID, R., 2010. Evaluation of wheat by polyacrylamide gel electrophoresis. African Journal of Biotechnology, vol. 9, no. 2, pp. 243-247.

SINGH, N.K., DONOVAN, G.R. and MACRITCHIE, F., 1990. Use of sonication and size-exclusion high-performance liquid chromatography in the study of wheat flour proteins II. Relative quantity of glutenin as a measure of bread making quality. Cereal Chemistry, vol. 67, pp. 161-170.

SINGH, S., SINGH, N. and MACRITCHIE, F., 2011. Relationship of polymeric proteins with pasting, gel dynamic and dough empiricalrheology in different indian wheat varieties. Food Hydrocolloids, vol. 25, no. 1, pp. 19-24. http://dx.doi.org/10.1016/j.foodhyd.2010.05.001.

SLUMIR, P., 2005. Principles of bread making. Functionality of raw materials and process steps. St. Paul: AACC, pp. 212.

SONG, Y. and ZHENG, Q., 2008. Influence of gliadin removal on strain hardening of hydrated wheat gluten during equibiaxial extensional deformation. Journal of Cereal Science, vol. 48, no. 1, pp. 58-67. http://dx.doi.org/10.1016/j.jcs.2007.08.001.

STOKLOSA, A.M., PERCHONOK, M.H., LITTLE, K.M., NIVENS, D.E. and MAUER, L.J., 2012. Effect of low dose gamma radiation on select wheat properties. International Journal of Food Properties, vol. 15, no. 1, pp. 109-121. http://dx.doi. org/10.1080/10942911003754668.

TEIXEIRA, C.A.H.M., INAMURA, P.Y., UEHARA, V.B. and MASTRO, N.L.D., 2012. Gamma radiation influence on technological characteristics of wheat flour. Radiation Physics and Chemistry, vol. 81, no. 8, pp. 1160-1162. http://dx.doi. org/10.1016/j.radphyschem.2011.12.014.

TOMIĆ, J.M. and TORBICA, A.M., 2011. Evaluation of technological quality of wheat using lab-on-a-chip electrophoresis. Food \& Feed Research, vol. 38, no. 2, pp. 63-68.
TORBICA, A., DRAŠKOVIĆ, M., TOMIĆ, J., DODIG, D., BOŠKOVIĆ, J. and ZEČEVIĆ, V., 2016. Utilization of Mixolab for assessment of durum wheat quality dependent on climatic factors. Journal of Cereal Science, vol. 69, pp. 344-350. http:// dx.doi.org/10.1016/j.jcs.2016.04.012.

VERAVERBEKE, W.S. and DELCOUR, J.A., 2002. Wheat protein composition and properties of wheat glutenin in relation to breadmaking functionality. Critical Reviews in Food Science and Nutrition, vol. 42, no. 3, pp. 179-208. http://dx.doi. org/10.1080/10408690290825510. PMid:12058979.

WALL, J.S., 1979. The role of wheat proteins in determining baking quality. In: D.L. LAIDMAN and R.G. WYN JONES, eds. Recent advances in the biochemistry of cereals. London: Academy Press, pp. 275-311.

WEEGELS, P.L., HAMER, H.J. and SCHOFIELD, J.D., 1996. Functional properties of wheat glutenin. Journal of Cereal Science, vol. 23, no. 1, pp. 1-17. http://dx.doi.org/10.1006/jers.1996.0001.

WIESER, H. and ZIMMERMANN, G., 2000. Importance of amount and proportions of high molecular weight subunits of glutenin for wheat quality. European Food Research and Technology, vol. 210, no. 5, pp. 324-330. http://dx.doi.org/10.1007/ s002170050558.

WIESER, H., 2007. Chemistry of gluten proteins. Food Microbiology, vol. 24, no. 2, pp. 115-119. http://dx.doi.org/10.1016/j. fm.2006.07.004. PMid:17008153.

WILLIAMS, J.F. and HUNT, J.W., 1963. Molecular lesions produced in ribonucleases by gamma rays. Nature, vol. 200, no. 4908, pp. 779-781. http://dx.doi.org/10.1038/200779a0. PMid:14087011

WRIGLEY, C.W. and BIETZ, J.A., 1988. Proteins and amino acids. St. Paul: American Association of Cereal Chemistry.

WRIGLEY, C.W., BÉKÉS, F., and BUSHUK, W., 2006, Gluten: a balance of gliadin and glutenin. In: Cereals \& Grains Assocation. Gliadin and glutenin: the unique balance of water quality. St. Paul: Cereals \& Grains Assocation, pp. 3-32. http://dx.doi. org/10.1094/9781891127519.002.

XIAO-LING, J., JI-CHUN, T., ZHI, H. and WEI-DONG, Z., 2008. Protein content and amino acid composition in grains of wheat-related species. Agricultural Sciences in China, vol. 7, no. 3, pp. 272-279. http://dx.doi.org/10.1016/S16712927(08)60066-8.

ZILIĆ, S., BARAC, M., PEŠIC, M., DODIG, D. and IGNJATOVICMICIC, D., 2011. Characterization of proteins from grain of different bread and durum wheat genotypes. International Journal of Molecular Sciences, vol. 12, no. 9, pp. 5878-5894. http://dx.doi. org/10.3390/ijms12095878. PMid:22016634. 